\title{
The Iapetus suture and the Scandinavian Caledonides
}

SIR - In a recent discussion of the possible location of the proto-Atlantic or Iapetus suture in SW Norway, Mason (1974) put forward cogent reasons for disputing Dewey's (1969) original notion and positioning of this palaeotectonic boundary, inferring that it must lie to the NW of the Norwegian landmass. I would like here just to point out that such a conclusion has already been reached by Nicholson (1971), Roberts (1971) and Gale \& Roberts $(1972,1974)$ on different and independent lines of evidence.

Dr Mason's evaluation of the evidence provided by the Jotun nappe and Jotun kindred rocks conforms to a large extent with accepted geological interpretation, yet it should be mentioned that geophysical studies by Smithson \& Ramberg (1970) and Smithson, Ramberg \& Grønlie (1974) indicated that the situation is not as clear-cut as previously supposed. Faunal and geochronological indications do indeed argue against the positioning of a suture line through this central part of the southern Norwegian 'faltungsgraben', as Smithson et al. (1974) acknowledged; yet the nappe geometry and large mass excess associated with the mafic rocks of the nappe suggest that the structure could represent a wedge of dense, lower crust rocks (Smithson et al. op cit.). Such a wedge of dense rocks could perhaps extend northeastwards beneath the metasediments of the Trondheim region and help explain some of the Silurian bilateral structural symmetry in that region. In some ways, therefore, particularly if the Jotun nappe really is an upthrust wedge within the Baltic Precambrian plate, the Jotun evidence could be regarded as not truly relevant to the question of the fossil consuming plate boundary.

Whether or not a flat-lying trace of the collisional plate boundary may be recognized in one of the several major thrust surfaces occurring throughout the Scandinavian Caledonides - and Mason follows Nicholson (1971) in suggesting this - is a delicate matter. These particular thrust surfaces are late, syn- to post-metamorphic thrusts which lack the characteristic features expected of consuming plate margins, a point also conceded by Nicholson (1974). The thrusts also post-date the major, Silurian obduction of oceanic and island arc basaltic lavas and overlying Ordovician-Silurian sediments (Gale \& Roberts, 1974). One or other of the higher-lying, westward-thinning, northcentral Scandinavian thrust sheets may well contain a sparse fauna of American or mixed American-European affinity and overlie Baltic basement, but the tectonic interface does not necessarily represent the suture of a past ocean merely because of this. Even if these upper thrust sheets do actually represent rocks which once overlay the Laurentian plate, it should be remembered that they are of restricted thickness and do not contain slices of Laurentian basement as would otherwise be expected had a flatlying collisional plate boundary been present, the conclusion being that the steeply dipping boundary or suture zone between the main mass of the two plates would have to have been located farther to the west. It could be argued that a more likely candidate for a flat-lying suture than the post-metamorphic thrusts would be the proposed obduction surface beneath the lowermost Ordovician, ocean floor and island arc, volcanic sequence of central and southern Norway. However, the Ordovician-Silurian volcanosedimentary pile, part of the Trondheim Supergroup, was itself derived from east of the site of southeastward oceanic lithosphere subduction, in a marginal basin situation (Gale \& Roberts, 1974). A wide variety of criteria, embracing greenstone and granite geochemistry, the zonation of mineral deposits and lithofacies variation, has provided confirmatory evidence for this general picture. Thus, we are led back to the original deduction that the line of suturing must lie off the present Norwegian coast.

Finally, I would like to take this opportunity to comment briefly on remarks received from several sources, including correspondence with Dr Mason, concerning the character of the southern Norwegian tholeiitic greenstones. It has rightly been pointed out that with the present state of knowledge these cannot be considered as ophiolites, either struc-

Geol. Mag. 112 (4), 1975, pp. 415-416. Printed in Great Britain. 
turally or petrologically, since they lack the characteristic sheeted dyke complex, gabbros and ultramafic assemblage. We have, in fact, never used the word 'ophiolite' in our publications, out of the simple recognition of the fact that such a complex in its entirety does not appear to exist within Norway: at least, none has been confirmed to date. There are pointers, however, one of which is the recent recognition of obducted hawaiitic volcanics associated with ultramafites on the island of Leka, $200 \mathrm{~km}$ NNE of Trondheim (Prestvik, 1974). Also, mafic dykes associated with gabbro and ocean floor-type lavas are known from certain areas, e.g. the Lokken area. Other fragments or slices of what may represent original ophiolite complexes may occur at other places in central Norway. There are some indications of this, but since detailed studies are lacking it would be premature even to speculate on these occurrences at this stage.

\section{References}

Dewey, J. F. 1969. Evolution of the Appalachian/Caledonian orogen. Nature, Lond. 22, $124-9$.

Gale, G. H. \& Roberts, D. 1972. Palaeogeographical implications of greenstone petrochemistry in the southern Norwegian Caledonides. Nature Phys. Sci., Lond. 238, 60-1.

Gale, G. H. \& Roberts, D. 1974. Trace element geochemistry of Norwegian Lower Palaeozoic basic volcanics and its tectonic implications. Earth Plan. Sci. Lett. 22, 380-90.

Mason, R. 1974. The location of the Iapetus suture in the Scandinavian Caledonides. Geol. Mag. 111, 439-42.

Nicholson, R. 1971. Faunal provinces and ancient continents in the Scandinavian Caledonides. Bull. geol. Soc. Am. 82, 2345-56.

Nicholson, R. 1974. The Scandinavian Caledonides. In Nairn, A. E. M. \& Stehli, F. G. (Eds.): The Ocean Basins and Margins, vol. 2, 161-203.

Prestvik, T. 1974. Supracrustal rocks of Leka, Nord-Trøndelag. Norg. geol. unders. 311, 65-87.

Roberts, D. 1971. Timing of Caledonian evorogenic activity in the Scandinavian Caledonides. Nature Phys. Sci., Lond. 232, 22-3.

Smithson, S. B. \& Ramberg, I. B. 1970. Geophysical profile bearing on the origin of the Jotun nappe in the Norwegian Caledonides. Bull. geol. soc. Am. 81, 1571-6.

Smithson, S. B., Ramberg, I. B. \& Grønlie, G. 1974. Gravity interpretation of the Jotun nappe of the Norwegian Caledonides. Tectonophysics, 22, 205-22.

Norges Geologiske Undersøkelse

DAVID ROBERTS

Trondheim

Norway

22nd November 1974

\section{The Cwm Dulyn rhyolite, Snowdonia}

SIR - Dr Wright has written concerning the possible extrusive nature of the Cwm Dulyn rhyolite dome. I share his expectations that extrusive rhyolite bodies not only occur but also may eventually be proven to occur in the Ordovician of Snowdonia. It is important therefore to evaluate as best we can the 3 pieces of evidence he presents in favour of an extrusive as opposed to an intrusive origin for the Cwm Dulyn dome (Wright, 1974).

\section{The overall field relations}

He states that the ignimbrite sheet has a quite gentle southerly dip in the immediate vicinity of the dome and refers the reader to his figure 2 as the evidence in support of this statement. It needs to be pointed out, however, that Wright's figure 2 is a near

Geol. Mag. 112 (4), 1975, pp. 416-418. Printed in Great Britain. 